\title{
GIFTS FOR A PUBLIC SERVANT: WHETHER IT IS WORTH TO COMPLY WITH THE RULES
}

\author{
Tetiana Kolomoets' ${ }^{1}$, Semen Stetsenko ${ }^{2}$, Anna Sharaia ${ }^{3}$ \\ Zaporizhzhia National University, Ukraine
}

\begin{abstract}
The article substantiates the expediency to distinguish a kind of "gift relations in the public service" - "gift relations with the participation of close persons of a public servant." The author draws attention to the specificity of the subjects of the relevant relations, which is a public servant (a person empowered to exercise the functions of the state or local self-government and "serve" for a public interest) and close persons of the public servant (persons connected with the public servant by means of family, friendly relations) A gift in these relations differs by peculiarity because it is oriented solely to the person of a public servant, and not to his professional activities, his special legal status. Its presentation does not imply any influence on the "purity" of the professional activities of a public servant. In view of this, it is inappropriate to consider the normative consolidation of the appropriate "personal" (it is also called "private", "ordinary", "normal") gift to requirements for cost, grounds, the periodicity of receiving. At the same time, despite the specifics of "gift relations with the participation of a public servant," they cannot remain outside the regulatory framework. Such regulation allows strengthening the foundations of determinacy in the "gift policy" of the state and eliminating the grounds for use of "gifts from close persons" as a means of "indirect" influence, including inappropriate, on the professional activities of public servants or concealment of unjust enrichment of the latter. The author justifies the inappropriate use of prohibitions and restrictions in the regulation of appropriate kind of "gift relations in the public service." Instead, the introduction of an obligatory annual declaration where public servants point all gifts, including "personal" ones, indicating donor's personality, the nature of the relationship with him, the market value of the gift. A similar obligation is proposed to provide for close persons of a public servant (first of all, family members as well as close persons who live together with a public servant) in order to strengthen the principles of transparency of "gift relations with the participation of close persons of a public servant," confirmation of the history of relationship, funds sources for gift's presentation (the indication of funds sources for the gift is mandatory for this group of persons). For the effective use of the declaration, proposals are formulated to unify the provisions of anti-corruption, tax and tort legislation in the aspect of compliance with the requirements for obtainment of gifts by public servants from their relatives.
\end{abstract}

Key words: close persons, public service, public servant, gift, corruption, declaration, rules, gift receiving.

JEL Classification: K00, K11, K19

\section{Introduction}

In the context of active search by the interested public, subjects of public administration of effective means of corruption prevention in the public service, increasingly the attention is focused on ones, the resources of which traditionally have been undervalued. "Gift prohibitions", "gift restrictions" occupy pride of place among them. However, it should be noted that, first of all, they are oriented to public servants and rightly so. They are empowered to implement the functions of the state and local self-government related to prohibition or restriction of gifts reception as means of influence on professional activity and should be oriented to such persons. Despite the relatively small, in cost nature, "influence power" of a gift on the professional activities of a public servant, it is not possible to evaluate it in the scale of public service as a whole. Due to the active use of the gift resource, it possible to achieve a significant influence on "purity" of the public service, which, in turn, will contribute to the growth and diversification of corruption in all its manifestations. It is that requires formation of the legislation that is a

\footnotetext{
Corresponding author:

${ }^{1}$ Department of Administrative and Commercial Law, Zaporizhzhia National University.

E-mail: t deputy@ukr.net

${ }^{2}$ Department of Administrative and Commercial Law, Zaporizhzhia National University.

E-mail: ssg777@ukr.net

${ }^{3}$ Department of Administrative and Commercial Law, Zaporizhzhia National University.

E-mail:an_any@rambler.ru
} 
perfect in content and effective in the application and which would regulate the principles of "gift policy in the public service" in all possible external forms of its manifestation. Despite the fact that in the legislation of a large number of countries of the world there are "gift prohibition", "gift restrictions" related to public servants, the rules of conduct with various types of gifts, the principles of public liability for non-compliance with the relevant provisions, unfortunately, "gift relations" with the participation of relatives of public servants are regulated rather fragmentarily. Practice also shows that such relations are quite common, and the possibilities (including inappropriate) of "gift influence" on a public servant in his professional activities through (or with the participation) his close persons is quite significant. For this reason, it is quite timely, logical, and justified to study the resource of "regulation of gift relations with the participation of close persons of a public servant" as an integral element of the modern "gift legal policy", which will allow formulating certain "rules of the game", the observance of which will eliminate the prerequisites for the use of a gift's potential as a "means of unlawful influence" on a public servant separately and public service as a whole. Regulatory fixation of the principles of the appropriate gift relations will contribute to effective counteraction to corruption in all its manifestations in the modern public service. All these facts lead to the formulation of the article purpose, which due to analysis of the resource of "gift relations in the public service with the participation of close persons of public servants" lies in the determination of the main guidelines of their regulatory control under the current conditions of activation of the prevention and counteraction of corruption in all its manifestations, thereby eliminated the "grey zone" that has been existing for a long time in the legal basis of such opposition and impedes the latter.

\section{The issue of "gift relations" in the public service in the legislation of different countries of the world}

It is worth to start from the fact that in the legislation of many countries the issue of "gift relations" in the public service has found its sufficiently detailed regulation as at the level of separate legislative acts (as a rule, it has anticorruption content (for example, Ukraine, Georgia) and as codified tortious acts (for example, Denmark, Great Britain, Finland, France, Germany), codified or other acts oriented to fix the ethical rules of conduct of public servants (for example, the USA, Brazil, Poland, Greece, Italy, Ireland). The principles of "gift relations" with the participation of public servants are regulated sufficiently detailed in the predominant majority of the relevant acts, which make sense. As they are called, using their powers, to realize the functions of the state or local self-government, in accordance with them the rules of conduct are regulated and the non-observance of which, in turn, leads to the possibility of bringing public servants to legal responsibility. Such an approach of the legislator is a logical as it is necessary to foresee the levers of prohibition, restriction on the activity of the person who, in the course of his professional activity, "serves the public interests." In relation to the activity of such person, it is necessary to foresee elimination (or minimization) of corruption risks, negative influence on "purity" of his professional activity. As a result, it is possible to find provisions in the legislation of the countries of the world that prohibit the receiving of gifts by public servants directly related to their professional activities (for example, China, Ukraine, Russia, Georgia, Germany, France), determine the maximum cost of gifts that public servants can receive from other persons as a manifestation of honour, respect for their bona fide professional activity (for example, in Singapore - fifty Singapore dollars, in Brazil - one hundred reals, in Denmark - one hundred and thirty euros), regulate the handling rules with various kinds of gifts as a "contact model" and "contactless model" of relations (for example, Standards of Ethical Conduct for Employees of the Executive Branch, Codified in 5 C.F.R, Part 2635 as Amended 76 FR 38547, the Law of Ukraine dated 14.10.2014 "On Prevention of Corruption" (art. 23, 24), the Resolution of Public Ethics Commission No. 3/00 (2000) on gifts to civil servants within the framework of the Code of Conduct for Senior Civil Servants in the Federal Executive Branch of Brazil (Certificate of Intent No. 37 on 18.08.2000 and Presidential Decree on 21.08.2000), the grounds of different types of legal responsibility for failure to comply with the relevant provisions. In scientific professional sources, the attention is also focused on "gift relations in the public service" with an emphasis on the principles of behaviour of public servants, prohibitions, restrictions on their activities, grounds for their liability for unlawful acts. It is possible to highlight several directions of enhanced scientific analysis of the relevant issue: a) with an emphasis on the specifics of regulatory consolidation and the practice of applying in a particular state (for example, in Brazil (Vasileva, 2015), Singapore (Gladchenko, 2014), Japan (Kolyshkyna), Russia (Gafurova, 2015), Ukraine (Kolomoiets, 2018), Slovenia (Nysnvevich, 2016), Indonesia (Tolmachev, 2016) etc.; b) in the aspect of comparative legal analysis through the example of several states (Zimneva, Chumakova, 2015) or a significant number of states (Kolomoiets, Verlos, Pyrozhkova, 2018); c) with the emphasizing of one or several problematic aspects of regulation (for example, the normative definition of a gift and its place in the contiguous conceptual series, the variety of gifts, the rules of gifts handling in different circumstances, the differentiation of principles of legal responsibility for breach of "gift rules", etc. (Bonsing, Langsted, 2013). At the same time, despite 
the availability of relevant scientific and normative thematic sources, the issues related to the regulation of "gift relations with the participation of close persons of public servants", unfortunately, are under-investigated and almost not regulated. Hence, there are issues which differ in their relevance. Whether public servants can receive gifts from their close ones? Whether it is possible to use close persons for unlawful influence on a public servant by means of "gift relations"? Whether a public servant uses "gift relations with close persons" as "external form" of concealing of corruption acts or acts connected with corruption? To answer these and concerned them the issue, it is necessary to analyse the resource of "gift relations of public servants with the participation of their close persons" taking into account the provisions of the legislation of different states designed to regulate these issues.

\section{Subjects of "gift relations of public servants with the participation of their close persons"}

First of all, it is necessary to focus on the subjects of these relations. Such are the public servant and his close persons. In relation to the first one, his main decisive feature is a special legal status, which consists in the fact that this person is authorized by the subject of public administration to perform functions of the state or local self-government and for this reason is lodged by a certain amount of public authority that can be used in the process of his public activity, "service to the public interest". Legislations of different states use several terms to indicate the appropriate group of persons. The most widespread are "public servant", "civil servant", "official of local self-government", "official”, etc. These terms form peculiar adjacent thematic terminology series. They are correlated with each other either as absolute synonyms or as adjacent synonyms of different volumes of regulatory notation. The legislator of each state establishes an official term and standard definition, which is the basis for the relevant legislation, to regulate "gift relations in the public service". For example, in Ukraine in special anti-corruption legislative act (the Law of Ukraine dated 14.10.2014 "On prevention of Corruption") the legislator, identifying the subjects covered by the relevant legislative act, offers their list (art. 3 of the Law) which can be divided into five groups: a) persons authorized to perform functions of the state or local self-government (they are still offered to be called "functionaries of the public sector"); b) persons who, for the purposes of the relevant Law, are equated with persons authorized to perform the above-mentioned functions (they are proposed to be conventionally called "quasi-functionaries of the public sector"); c) persons who are permanently or temporarily hold positions related to the implementation of organizational-management or administrative duties, or specifically authorized to perform such duties in legal entities of private law (so-called "functionaries of private sector"); d) candidates for post of elected positions, as well as candidates for headman post ("candidates for certain positions of functionaries of public sector"); e) other persons (so-called "non-functionaries") (Khavroniuk, 2018). At the same time, one article uses several terms as "civil servants", "officials of local selfgovernment", "servicemen", etc., and their definition is fixed in other legislative acts (on civil service, service in local self-government bodies, diplomatic service, etc.). The analysis of the content of the latter allows separating the indication of the "public" nature of activity, empowerment, and service (therefrom "service") to the public interest.

Georgian legislator chose somewhat different approach to the solution of this issue. Thus, in the Law of the Republic of Georgia dated 21.12.2016 "On the Conflict of Interests and Corruption in Public Institution", the basic term is "public servant". And although, the legislator does not propose the very definition of a public servant in this legislative act, at the same time, it notes that for the purposes of this act, a public official is "public servants" introduced by the Law of Georgia "On Public Service” as well as persons engaged in activities in institutions that are equated with state ones. In addition, they are not persons performing auxiliary functions (auxiliary servants) (art. 2-1 of the Law). At the same time, the legislator moves on and clarifies its position, indicating that public servants (accordingly for gift relations too) are considered civil servants, professional public officials (officials), persons who work in the public service under an administrative contract (art. 2-1 of this same Law). In order to eliminate the grounds for free interpretation of the provisions of the legislation on this issue, the legislator, using the term "official" to denote the subjects of service (including gift) relations, proposes their list (art. 2 of the same Law) (On the Conflict of Interests and Corruption in Public Institution dated 21.12.2016 No 157. As we see, in spite of the use of various terminology to determine the subject of "gift relations", it can be said that the term "public servant" is used as a generalized to the rest, and features that are inherent to the subject of "gift relations" are typical for the laws of any state, which allows asserting that this subject of "gift relations" is a special subject, a subject with a special legal status.

In relation to another subject of the relationship, it should be noted the following. In the legislation of different countries, you can find different terms for its determination: "family members", "close persons", "close relatives”, etc. Despite their relative external similarity, they should not be confused and it is necessary to focus on the one, who is detached by the legislator as another subject of "gift relations". For example, in Ukraine, these are "close people" (art. 23 of the Law) and they should be clearly distinguished from "family members" (art. 1 of the same Law). Consequently, in Ukraine, 
"close persons" are offered to be recognized as persons who can be divided into two groups: a) those who in any circumstances are considered as such (their list is given, beginning from "husband, wife, father, mother, and even to a person who is under guardianship or care); b) those for the recognition of which as close persons there is necessity of three features, namely: joint residence, connection with a common life, the existence of mutual rights and responsibilities with mentioned person - a public servant. So, listing the first group of people, for some reason, it was forgotten about niece (nephew), uncle (aunt), groom (bride), greatgrandfather (great-grandfather), thereby arbitrarily drawing the degrees of kinship (Khavroinuk, 2018). Separating the second group of people, the legislator offers their features, the proof of which in practice is associated with significant difficulties, as evidenced by the generalization of the results of a trial of cases over non-compliance with restrictions on the receipt of gifts by public servants. Under these conditions, the question arises, whether a public servant can get a gift from his friend or neighbour? It is impossible to attribute such persons to "close persons" according to the above-mentioned features, although such practice of presentation of "personal gifts", "private gifts" is very common in different countries. The conditions of "gift relations" can be complicated - the receipt of gifts by a public servant from a person who carries out any activity in the sphere of realization of the functions of the state or local self-government by a public servant, if there is a long-lasting friendly relationship between the two persons. Is it possible to receive gifts under such conditions? This person does not belong to the category of "close persons", and at the same time "subordinate person" in the classical sense cannot be recognized as such.

The legislation of Georgia uses another term - "close relatives" (family members, lineal relatives, stepchildren, sisters, brothers, and stepchildren of parents and children of a person) (art. 4 of the Georgian Law). In addition, relatively "gift relations", it is proposed to use the term "family members" (husband, wife, minor children, stepsons (stepdaughters) of a person, as well as persons who permanently reside with a person (art. 4 of the Law). Such an approach to the definition of the subjects of "gift relations in the public service" looks more considered as in the process of law enforcement it involves the concentration of attention either on family ties or on a joint permanent residence, eliminating the need to prove common life, etc. But nevertheless, the issue of a gift from a friend or a neighbour remains open. In this aspect, the US approach to the solution of this issue looks interesting, namely: among the whole variety of gifts, there are "gifts made on the basis of personal relationships". That is, the legislator allows a public servant to receive a gift from a person with whom is "in family or friendly relationship, and not in relation to a position of service" ( $\$$ 2635. 204 Standards of Ethical Conduct for Employees of the Executive Branch, Codified in 5 C.F.R, Part 2635 as Amended 76FR 38547). However, there must be evidence of "history of relationships", the facts of payment of a gift by members of a family or friends of a public servant, etc. This type of gifts is also called "private gifts", "personal gifts", "normal gifts" due to their disconnection with the professional activities of a public servant, and vice versa, its direct connection with a person, his private life (Bonsing, Langsted, 2013).

Thus, to specify another subject of "gift relations in the public service", despite the use of a large number of different terms, the emphasis is laid on its direct connection with the person of a public servant, his private life by means of the normative consolidation of the conditions of family, friendly relations, common, permanent residence, the existence of a common way of life, mutual rights, responsibilities, etc. Connection with the professional activities of a public servant, a desire to influence in any way such activities, including its "purity", should remain outside of attention for this subject. Despite the variety of terms used to identify this subject of "gift relations", it can be argued that there are conditionally two approaches of the legislator to resolve this issue. The first one is narrow, indicating a family relationship with a public official (prevalent use "family members", "close relatives", "family members"), and the second one is wide, indicating both family and other personal (person-related) ties (prevalent use of the term "close persons", that is, persons "who are (stay) close, beside"). For the purposes of law enforcement, taking into account existing practices, it is expedient to use the term "close persons", however, with the normative consolidation of all diversity of the manifestation of personal relations. This will allow eliminating "grey zone" in the terminology series of normative grounds for the definition of the subjects of "gift relations in the public service" and the dividing of so-called "personal" gifts as a separate kind of gifts.

\section{Specification of gifts in "gift relations with the participation of close persons of a public servant"}

It is important to find out what exactly can be considered as gifts in "gift relations with the participation of close persons of a public servant”. A generalized analysis of the legislation of different countries shows that the basic approach in the normative resolution of this issue is an enumeration of possible external forms of gift existence (however, the number of such forms and the sequence of their mention in the corresponding list differ). For example, a gift (it should be clearly noted that the official definition is also fixed either in a special anti-corruption legal act, or in an act that consolidates the principles of ethical conduct of public servants, or 
in another act, the content of which is "oriented" to regulate relations of public service) is recognized as "a reward that has the form of any material wealth with value sense (including money, fees, securities, debts relief, services, benefits, privileges, etc.)" (in Singapore), "money reward, refraining from actions or other actions or things that may have money term, as well as services, payment of expenses on education, transportation, local travel, accommodation, meals in natural or in any other form" (in the US), "funds or other property, benefits, privileges, services, intangible assets that are provided free of charge or at below minimum market price" (in Ukraine) (Kolomoiets, 2018). Thus, it is traced the legislator's desire to enumerate as much as possible potential external forms of expression of a gift and to emphasize the presence of their value feature, which is also quite logical. The basic definition of "gift" is used for "gift relationship with the participation of close persons of a public servant" as well as for any other types of "gift relations in the public service". However, it has already been noted the expediency of distinguishing a special kind of gift - "personal", "private", "ordinary", which should be used in the analysis of "gift relations with the participation of close persons of a public servant." This raises the question: if this is a special kind of gift, there should be its special features, which distinguish it from all variety of gifts. What are its specific features? Taking into consideration the specifics of "gift relations with the participation of close persons of a public servant" in the aspect of their subjects, as already noted, one could argue that a gift in such relationships should be characterized by its exclusive personal (in relation to the person of a public servant) orientation, connection with relatives, friendly relations with the person provides it (offers). Hence, it is quite logical to assume that the legislation should not consolidate any restrictions (indications at all) for this type of gifts regarding its value, grounds, the frequency of receipt, etc. Otherwise, it contradicts the expediency of separation and hence the existence of such kind of gift that is directly related to a person, and not with his special legal status, professional activity, the sphere of activity, etc. The exclusively personal orientation of such a gift is directly connected with the grounds for its presentation (receipt), which also should be directly related to the personal life of a public servant, a history of the relationship with a close person who gives this gift. Consequently, any events in the life of relevant subjects such as birthday, marriage, the anniversary of friendly relations, the birth of a child, etc., can serve as legal facts for the emergence of "gift relations with the participation of close persons of a public servant". In practice, in general, there should be no difficulties associated with the attribution of a gift for a public servant from his close person to "personal" ("private", "ordinary"). If the person who gives (offers) a gift to a public servant is his close person in accordance with the provisions of the current national legislation and this fact is confirmed by the history of their relations, there are reasons to consider it as "personal" ("private", "ordinary"). There should not be any indications in the legislation relatively its correspondence to any visions of hospitality, historical or national traditions of gifts presentation, communicating, maintenance of friendly or family relationships, as this gift is not related to the professional activities of a public servant, his special legal status, it is not foreseen the possibility to use it for any (including unlawful) influence on the "purity" of his professional activities. There should not be any risks from such a gift for public service. At the same time, unfortunately, in the practice there are cases of the use of so-called "complicated gift relations with the participation of close persons of public servants", when close persons of a public servant act as "mediators" in gift relations. That is why it is impossible to remain "gift relations with the participation of close persons of a public servant" without normative regulation. An analysis of the provisions of the legislation of different states suggests that in most cases, it is consolidated the provision that public servants are allowed to receive gifts from close persons. This is quite justifiable. However, there are no any restrictions relatively their quantity, cost, the frequency of receipt, correspondence of gifts with certain criteria of content, which again is quite justified. At the same time, the state should regulate the appropriate "gift relations" using other than prohibitions or restrictions, methods to eliminate the misuse of the resource of such relationships.

\section{Introduction of the obligation of annual declaring of gifts for a public servant}

The introduction of the obligation for a public servant to declare estate, including from relatives, gifts every year looks optimally. This practice has been quite widespread in different countries for a long time and has approved itself positively. For example, in Latvia declaration of gifts is mandatory for all public servants, including both for those who hold election posts and parliamentarians, in Germany, Spain, and the United Kingdom, the declaration of gifts is mandatory for those who hold political post and for members of parliament, while in Hungary this obligation applies only to members of parliament. In Poland, gifts are declared only by those who hold elective posts at the local level and political positions, while in France, parliamentarians declare all state gifts regardless of their value. (Villoria, Synnerström, Bertok, 2010). It is important that the legislation should stipulate that gifts are subjected to the mandatory declaration, incl. received from relatives, whose value on the day of reception exceeds a certain clearly defined amount. The latter may equal to the value of the so-called "allowed" gifts for a public servant that can mediate his professional activities (in the UK - 140 pounds sterling, in Russia - three thousand 
roubles, in Singapore - fifty Singapore dollars, in Ukraine - one living wage for an able-bodied person at a one-time reception of a gift, etc.). It is important to consolidate the duty of a public servant to declare this gift, indicating its market value and the person who provided it. In addition, it should be clearly understood that the institute resource of the "declaration of gifts in the public sphere" should be used systematically: the law should have a unified approach to the determination of all, including "personal" ("private", "normal") gifts in the aspect of their value, the obligation to indicate the identity of the donor (in order to, in case of doubt, determine the sources funds for the corresponding gift). It is necessary to introduce the obligation of family members of public servants to declare incomes and expenses, including and in a part of the gifts given to a public servant, thereby eliminating the collision that exists to date in the legislation of most states on this issue (a public official, submitting a declaration, must also indicate the information of family members, although the latter are not obliged to do so and they are not legally responsible). The introduction of such practices will contribute to the clearness of "gift relationships with family members" regarding the reliance that this gift was purchased at their own expense. The same rules can be extended to close people who live together with a public servant and those who are "as close as possible" to the possibility of "indirect influence" on the professional activities of a public servant through a gift for him. Implementation of a mandatory declaration by them, including gifts given to a public servant, will contribute to the certainty of the appropriate kind of "gift relations in the public service" (first of all, in terms of the legality of funds sources). As for the relatives as a whole, the introduction of total declaration in the country is possible only under certain conditions, taking into account the priorities of domestic policy, time limits, and therefore, in the long run, this is a very real mechanism for monitoring the "gift relations with the participation of close persons of public servant." Under such conditions, close persons will be obliged to declare the gifts given to a public servant, indicating the sources of funds for this. By this moment, it is logical to declare "personal" ("private, "ordinary") gifts received from close friends annually by a public servant, indicating the person who provided the present, the market value of this gift. That, in turn, will provide an opportunity for anti-corruption actors and the interested public, if there are doubts, to concentrate their attention on the close person of a public servant in order to find out the reasons for the emergence of "gift relations". It should be noted that in the legislation of some countries such provisions have already been consolidated (for example, Georgia, Singapore). Thus, taking into account the specifics of the appropriate variety of "gift relations in the public service", the optimal means of their regulation is the introduction of declaration of things by the subjects of these relations, with the simultaneous unification of the provisions of anti-corruption (in terms of regulation of "gift relations") and tax legislation (declaration duty, value nature of the gift should be declared, indication of the donor's person and the nature of the relationship with him/her, etc.), the introduction of legal liability for the breach of the obligation to declare, strengthened the guarantees of performance of duty, eliminating the grounds for the existence of "indirect gift relations with the participation of close persons of a public servant" (when such persons are actually used to conceal the receipt of "prohibited gifts", which are directly related to professional activities of a public servant to influence the impartiality, bona fide of his professional activities). It is important to note that provisions of the tort law in the terms of identification of the principles of legal liability for failure to comply with the obligations by the subjects of "gift relations with the participation of close persons of a public servant" in general, regarding declarations must be consistent with the realities of time, anticipate such measures of responsibility that would be balanced with the nature of the commissioned unlawful act, would involve the achievement of the goal of prevention, education, and adequate punishment and would be effective in its application.

\section{Conclusions}

In the context of the search for the best means to prevent and combat corruption in all its manifestations, corruption offenses in the public sphere, it is important to define the legal principles of "gift relations in the public service". Among the diversity of "gift relations in the public service," it should be distinguished a special kind - "gift relations with the participation of close persons of a public servant". The latter are directly related to the receipt of "personal" ("private", "ordinary") gifts by public servants from persons with whom public servants are related by family, friendly relations, including for a long period of time. Nevertheless, in order to eliminate the prerequisites for the illegal use of the resource of "personal" ("private", "ordinary") gifts, the law should consolidate the basic principles of regulation of relations associated with the receipt of gifts by public persons from close persons. It will allow avoiding so-called "indirect gift relations in the public service" associated with the use of close persons as "hidden links" in "gift relations", aimed at influence on, including illegal, impartiality and honesty of the professional activities of a public servant, on the "purity" of the public service as a whole. In order to resolve this issue, it is considered important: a) the awareness that the subjects of the appropriate kind of "gift relations" are a public servant (a person with a special legal status who has a certain amount of authority to implement the functions of the state or local selfgovernment, "service" to the public interests) and close persons (persons connected with a public servant by 
family, friendly, including long-term relationships) that requires the regularization of the official terminological series and normative consolidation of definitions "close people", "family members" (the first of which differs by generalized nature and covers other); b) the distinction among all diversity of gifts in the public service of the "personal" ("private", "ordinary") gift directly oriented to the person of a public servant without any connection with his professional activities, special legal status, possibility of any influence on the "purity" of his professional activities. It, in turn, makes it possible to use the existing norm of the definition "gift for a public servant" for the purpose of its distinguishing in terms of enumeration of possible external forms of its existence. At the same time, it is inappropriate to fix any features of its value, reasons, frequency of receipt, and compliance with certain notions related to this kind of the gift as it is contrary to the nature of "gift relations with the participation of close persons of a public servant"; c) it is impossible and inexpedient to regulate this kind of "gift relationship" by means of the use of any restrictions or prohibitions, at the same time, these relations cannot be outside the regulatory influence. In order to resolve this issue, it is possible to introduce a mandatory annual declaration by a public official of all received "personal" ("private", "ordinary") gifts with an indication of the person who provided them, the nature of the relationship with him, the market value of this gift. To strengthen control over compliance with the requirements for the legislation on the "purity" of public service, it is expedient to secure the normative consolidation of the obligatory declaration by family members and close persons of a public servant (who live together, and in the future, by all persons), and on gifts provided by them to a public servant with indication of the funds sources for it. All "personal" ("private", "ordinary") gifts should be declared, the cost of which exceeds the value nature of "permitted" gifts for the receipt by public servants related to the professional activity. In the context of unification of the provisions of the national anti-corruption, tax and tort (in terms of the principles and measures of liability for non-compliance with the mandatory annual declaration) legislation, it is possible to achieve a positive result in the effective use of the resource of "personal" ("private", "ordinary") gift for a public servant.

\section{References:}

Vasileva, V.M. (2015) Regulirovanie konflikta interesov na gosudarstvennoy sluzhbe: Brazilskiy opyt (chast 2) [Regulation of conflict of interests in public service: the Brazilian experience (part 2)]. Voprosy gosudarstvennogo $i$ munitsipalnogo upravleniya, vol. 3, pp. 165-190.

Gladchenko, L.V. (2014) Ob opyte Singapura po protivodeystviyu korruptsii [On Singapore's experience in countering corruption]. Problemy natsionalnoy strategi, no. 3 (24), pp. 126-138; Astafyeva, E.M. (2016) Borba s korruptsiey v Singapure: strategiya i praktika [Fight with corruption in Singapore: strategy and practice]. Aziya $i$ Afrika segodnya, vol. 1, pp. 52-59.

Kolyshkyna, S.S. Korruptsionnye skandaly v Yaponii na rubezhe XX - XXI vv. [Corruption scandals in Japan at the turn of the XX - XXI centuries.]. Retrieved from: http://syberleninka.ru/article/u/

Gafurova, A. Kh. (2015) K voprosu o darenii predmetov roskoshi, kak izmenchivoy sostavlyayushchey etapov razvitiya obshchestva. Osobennosti polucheniya podarkov gosudarstvennymi sluzhashchimi [On the issue of presentation of luxury goods as a volatile component of the stages of society development. Peculiarities of gifts receipt by civil servants]. Vestnik KGU imeni N.A. Nekrasova. Yuridicheskie nauki, no. 6, pp. 169-172.

Kolomoiets, T. O. (2018) Obmezhennia shchodo oderzhannia podarunkiv osobamy, upovnovazhenymy na vykonannia funktsii derzhavy abo mistsevoho samovriaduvannia za zakonodavstvom Ukrainy: naukovopraktychnyi komentar [Restrictions on the reception of gifts by persons authorized to perform functions of the state or local self-government under the legislation of Ukraine: scientific and practical commentary]. Zaporizhzhia: Publishing House "Helvetica", pp. 40.

Nysnvevich, Yu.A. (2016) Protivodeystvie korruptsii: fenomen Slovenii [Anti-corruption: the phenomenon of Slovenia]. Mezhdunarodnaya ekonomika i mezhdunarodnye otnosheniya, issue 60, vol. 3, pp. 36-48.

Tolmachev, N.A. (2016) Borba s korruptsiey v Indonezii na sovremennom etape [The fight against corruption in Indonesia at the present stage]. Problemy Dalnego Vostoka, no. 4, pp. 93-99.

Zimneva, S., Chumakova, A. (2015) Legal Regulation of Civil Servants in Russia and Germany Receiving Gifts. Russian Law Journal, vol. III, issue 3, pp. 142-151.

Kolomoiets, T., Verlos, N., Pyrozhkova, Y. (2018) Gift for a Public Servant - a Manifestation of Respect, Reward or a Means of Unlawful Influence. Baltic Journal of Economic Studies. Riga: Publishing House "Baltia", vol. 4, no. 1, pp. 227-234.

Bonsing, S., Langsted, L. (2013) Gifs for Public Employees: An Administrative and Criminal Law and Criminal Justice. Undue, no. 21, pp. 163 - 184.

Khavroniuk, M.I. (ed.) (2018) Naukovo-praktychnyi komentar Zakonu Ukrainy «Pro zapobihannia koruptsii» [Scientific and practical commentary of the Law of Ukraine "On Prevention of Corruption"], Kyiv: Vaite.

O nesovmestimosti interesov i korruptsii v publichnykh uchrezhdeniyakh: Zakon Gruzii ot 21.12.2016 goda № 157 [On the Conflict of Interests and Corruption in Public Services: the Law of Georgia dated 21.12. 2016 No 157] Retrieved from: https://matsne.gov.ge/ru/document/download/33550/55/ru/pdf 
Kolomoiets, T. O. (2018) Obmezhennia shchodo oderzhannia podarunkiv osobamy, upovnovazhenymy na vykonannia funktsii derzhavy abo mistsevoho samovriaduvannia za zakonodavstvom Ukrainy: naukovopraktychnyi komentar. [Restrictions on the reception of gifts by persons authorized to perform functions of the state or local self-government under the legislation of Ukraine: scientific and practical commentary]. Zaporizhzhia: Publishing House "Helvetica", pp. 40.

Villoria, M., Synnerström, S., Bertok, J (2010) Etyka derzhavnoi sluzhby: zapobihannia konfliktu interesiv ta vymohy do zakonodavstva [Ethics of the civil service: prevention of conflict of interests and requirements to legislation]. Kyiv: Centre for Adaptation of the Civil Service to the standards of the European Union, pp. 104. 